\title{
EFEKTIVITAS PENGGUNAAN ASAM SITRAT DALAM PEMBUATAN GELATIN TULANG IKAN BANDENG (CHANOS-CHANOS FORSKAL).
}

\author{
Dewi Fatimah $^{1}$; Akyunul Jannah ${ }^{2}$ \\ Jurusan Kimia, Fakultas Sains dan Teknologi, Universitas Islam Negeri Maulana Malik Ibrahim \\ Malang \\ 2008
}

\begin{abstract}
ABSTRAK
Tulang ikan bandeng merupakan by-product perikanan yang dapat diperoleh dari industri pengolahan ikan. Selama ini tulang ikan bandeng masih belum termanfaatkan. Guna meningkatkan nilai ekonominya tulang ikan bandeng berpotensi sebagai bahan baku pembuatan gelatin halal. Gelatin merupakan hasil hidrolisis parsial kolagen yang diperoleh melalui ekstraksi dalam air panas yang dikombinasikan dengan perlakuan asam atau basa. Gelatin dapat berfungsi sebagai pengemulsi (emulsifier) dan penstabil (stabilizer) dalam sistem emulsi. Penelitian ini bertujuan untuk mempelajari salah satu alternatif pembuatan gelatin halal dengan pemanfaatan tulang ikan bandeng yaitu sebagai bahan baku dengan proses asam, serta mengetahui konsentrasi asam sitrat dan lama perendaman optimum terhadap produksi dan karakteristik gelatin yang dihasilkan. Rancangan percobaan yang digunakan adalah yang pertama penentuan konsentrasi asam sitrat optimum dengan variasi konsentrasi $1 \%, 3 \%, 5 \%, 7 \%$ dan $9 \%$. Kedua adalah penentuan lama perendaman optimum menggunakan konsentrasi optimum hasil penelitian dengan variasi waktu 12 jam, 24 jam, 32 jam, 48 jam dan 60 jam. Karakterisasi gelatin dilakukan dengan menentukan beberapa sifat fisik maupun kimia gelatin. Parameter yang diamati adalah kadar air, kadar abu, kadar protein, kekuatan gel, titik leleh, warna, aroma dan rasa. Identifikasi gugus fungsi gelatin dilakukan pada sample terbaik menggunakan Spektroskopi FT-IR. Data hasil uji sifat-sifat gelatin yang diperoleh dianalisis secara deskriptif. Untuk menentukan perlakuan terbaik dilakukan dengan menggunakan metode de garmo. Konsentrasi optimum asam sitrat untuk ekstraksi gelatin adalah $9 \%$ dengan lama perendaman 48 jam. Gelatin yang dihasilkan memiliki kadar air sebesar 6,68 $\%$, kadar abu 0,033 \%, kadar protein 9,56 \%, titik leleh 71,83C, kekuatan gel 38,72 mm/g.dt, warna 4,23, aroma 3,0 dan rasa 2,88 dengan rendemen sebesar 9,74\%. Berdasarkan spektra FT-IR gelatin tulang ikan bandeng, gugus fungsi yang dapat diidentifikasi diantaranya adalah gugus $O-H, N-H, C-N, C=O \& C-H$.
\end{abstract}

Kata Kunci : Tulang Bandeng, Hidrolisis, Asam Sitrat, Kolagen dan Gelatin

\begin{abstract}
The milkfish bone is by-product from fishery product and has not used optimally. To increase the economical of milkfish bone, it can be an alternative basic material gelatin to change unlegally usual basic material.Gelatin produces from the collagen partial hydrolyses by hot water extraction combined of acid or base treatment.

This research is aimed to study one of alternative in making Gelatin legally using milkfish skin by acid's process, to know the optimum concentration of citric acid by variation 1\%, 3\%, 5\%, 7\%, and 9\%,to know optimum soaked time by variation time 12, 24, 32, 48 and 60 hours and to know the characteristics of produced Gelatin. The group function identification of Gelatin is done at the best sample used Spectroscope FT-IR. The best treatment was got by using de garmo method. The optimum citric acid concentration for Gelatin's extraction is $9 \%$ for about 48 hours. It has the water's value by $6.68 \%$, dust by $0.033 \%$, protein by $9.56 \%$, melt point by $71.83 \mathrm{C}$, gel by $38.72 \mathrm{~mm} / \mathrm{g} . \mathrm{dt}$, color by $4.23 \%$, aroma by 3.0 and taste by 2.88 with the rendement by 9,74\%. From the FT- IR Spectra, the group functional which can be identified at gelatin milk fish is group of $O$ $\mathrm{H}, \mathrm{N}-\mathrm{H}, \mathrm{C}-\mathrm{H}, \mathrm{C}=\mathrm{O}$ and $\mathrm{C}-\mathrm{H}$.
\end{abstract}

Keywords : Ikan bandeng, Hydrolyses, Sitrat acid, Collagen and Gelatin

\footnotetext{
${ }^{1}$ Mahasiswa Jurusan Kimia Fakultas Sains dan Teknologi, UIN Maliki Malang

${ }^{2}$ Dosen di Jurusan Kimia Fakultas Sains dan Teknologi, UIN Maliki Malang
} 


\section{PENDAHULUAN}

Gelatin merupakan protein hasil hidrolisis parsial kolagen tulang dan kulit. Penggunaan gelatin sangat luas khususnya dalam bidang industri, baik industri pangan maupun non pangan. Gelatin memiliki sifat yang khas, yaitu berubah secara reversible dari bentuk sol ke bentuk gel, mengembang dalam air dingin, dapat membentuk film serta mempengaruhi viskositas suatu bahan, dan dapat melindungi sistem koloid. Kelarutannya dalam air membuat gelatin diaplikasikan untuk keperluan berbagai industri (Wahyuni, 2003). Indonesia mengimpor gelatin dari negara-negara seperti: Perancis, Jepang, India, Brazil, Jerman, China, Argentina dan Australia. Impor gelatin tahun 2000 mencapai 2.700 ton telah meningkat menjadi 6.233 ton lebih pada tahun 2003 atau senilai US \$ 6.962.237 (Peranginangin, 2007 : 3). Produksi gelatin pada umumnya menggunakan kolagen yang berasal dari tulang dan kulit ternak, yaitu sapi dan babi. Penggunaan bahan ini ternyata menimbulkan masalah tersendiri bagi para penggunanya. Penggunaan tulang dan kulit sapi akan menjadi masalah bagi para pemeluk agama Hindu, sementara itu penggunaan bahan dari babi akan menjadi masalah bagi para pemeluk agama Islam dan Yahudi. Di sisi lain, maraknya penyakit sapi gila (mad cow disease), penyakit mulut dan kuku (foot and mouth disease) dan Bovine Spongiform Encephalopathy (BSE) yang menyerang sapi di banyak negara dikhawatirkan akan menjadi masalah bagi konsumen. Alternatif lain adalah menggunakan sumber kolagen dari ikan, yaitu kulit dan tulangnya yang sebenarnya merupakan limbah industri pengolahan ikan (Peranginangin, 2007). Tulang dan kulit ikan (toleostei) merupakan limbah dari proses pengolahan hasil perikanan yang selama ini tidak dimanfaatkan dan akan menimbulkan kerugian terutama pencemaran lingkungan jika dalam jumlah besar. Penggunaan toleostei dapat dijadikan sebagai suatu alternatif non konvensional untuk mencari sumber gelatin selain dari kulit dan tulang babi (Wahyuni, 2003). Dalam perspektif agama Islam, penggunaan tulang dan kulit ikan sebagai bahan baku pembuatan gelatin, dapat dijadikan sebagai alternatif gelatin halal, sebagaimana dijelaskan dalam al-Qur'an surat Al-Ma'idah ayat 96 di atas (Anwar, 2007 : 3). Hampir semua jenis ikan berkulit dan berduri dapat diambil gelatinnya. Gelatin dapat dibuat dari ikan laut maupun ikan air tawar. Jenis ikan laut yang potensial menghasilkan gelatin antara lain ikan pari, ikan kakap dan cakalang. Ikan dari perairan tawar yang berpotensi menghasilkan gelatin misalnya ikan nila (Pranoto, 2006). Jannah (2007), menyebutkan bahwa lamanya perendaman akan mempengaruhi kelarutan kolagen dalam pelarut asam. Waktu perendaman yang lebih baik adalah dibawah 6 hari. Oleh karena itu, Perlu dilakukan penelitian lebih lanjut mengenai penggunaan konsentrasi pelarut yang sesuai dan lama perendaman yang dibutuhkan untuk memperoleh gelatin dengan kualitas terbaik. Untuk menemukan kondisi optimum ekstraksi gelatin dari tulang ikan bandeng dilakukan penelitian ini yang terfokus pada pencarian konsentrasi asam sitrat dan waktu perendaman yang optimum untuk ekstraksi gelatin tulang ikan bandeng.

\section{METODOLOGI}

\subsection{Bahan}

Tulang ikan bandeng yang diperoleh dari limbah perikananan di daerah Sindujoyo Gresik, asam sitrat, aquades, $\mathrm{H}_{2} \mathrm{SO}_{4}, \mathrm{Na}_{2} \mathrm{SO}_{4}{ }^{-}$ $\mathrm{HgO}(20: 1), \mathrm{NaOH}-\mathrm{Na} 2 \mathrm{~S} 2 \mathrm{O} 3$, butiran zink, $\mathrm{HCl}$, larutan jenuh asam borat dan indikator metil merah.

\subsection{Alat}

Bak perendaman, panci perebusan (stainless steel), kompor gas, pengaduk, cawan porselin, gelas piala, tabung kapiler, termometer, penangas, oven elektrik, timbangan elektrik, tanur, almari pendingin, spektrofotometer FT-IR, rotary evaporator, labu Kjeldahl, rangkaian alat destilasi, spatula, statif, dan desikator. 


\subsection{Preparasi Sampel}

\subsubsection{Pembersihan Tulang}

Tulang ikan dipisahkan dari daging dan kulitnya, lalu dimasukkan dalam bak dan diaduk-aduk, kemudian airnya dibuang.

\subsubsection{Degreasing Tulang}

Tulang ikan direndam dalam air dengan temperatur antara $70-80^{\circ} \mathrm{C}$ selama 2 jam. Kotoran yang mengambang dan buih dibuang. Setelah itu tulang ditiriskan, kemudian dikeringkan.

\subsubsection{Penentuan Konsentrasi Optimum Asam Sitrat dalam Perendaman Tulang Ikan bandeng}

Sebanyak 250 gr tulang kering direndam dalam larutan asam sitrat $1 \%$. Perbandingan berat sampel dan volume pelarut adalah 1:3 dengan lama perendaman 24 jam. Selama perendaman dilakukan pengadukan. Setelah itu tulang dicuci dan disemprot dengan air sehingga kotoran dan larutan asam sitrat yang menempel pada tulang terbuang. Perlakuan tersebut diulang secara triplo. Perlakuan diatas diulang dengan prosedur yang sama dalam asam sitrat $3 \%, 5 \% .7 \%$ dan $9 \%$. Kemudian dilanjutkan dengan proses ekstraksi gelatin.

\subsubsection{Ekstraksi Gelatin Tulang Ikan Bandeng}

Gelatin di dalam tulang diekstrak dengan air panas yang bersuhu $50-80^{\circ} \mathrm{C}$. Ekstrasi dilakukan dengan merendam tulang di dalam air panas 3 tahap, yaitu:

\section{a. Ekstraksi Gelatin pada Suhu 50}

Sebanyak 250 gr tulang hasil perendaman dengan asam sitrat direndam di dalam air bersuhu $50^{\circ} \mathrm{C}$ selama 4 jam. Selama perendaman, dilakukan pengadukan. Setelah perendaman, tulang dikeluarkan, dan cairan perendaman dipindahkan ke wadah penguapan larutan gelatin. Larutan kental ini disebut larutan gelatin tahap I.

\section{b. Ekstraksi Gelatin pada Suhu $65^{\circ} \mathrm{C}$}

Tulang yang diangkat dari air panas tahap I, langsung dimasukkan ke dalam air panas yang bersuhu $65{ }^{\circ} \mathrm{C}$. Selama perendaman dilakukan pengadukan. Lama perendaman adalah 4 jam. Setelah perendaman selesai, tulang segera diangkat, dan cairan perendam dipindahkan ke wadah penguapan larutan gelatin yang telah berisi larutan gelatin dari tahap I.

\section{c. Ekstraksi Gelatin pada Suhu $80^{\circ} \mathrm{C}$}

Sementara melakukan ekstraksi tahap II, telah disiapkan air panas bersuhu $80{ }^{\circ} \mathrm{C}$ tersebut. Selama perendaman dilakukan pengadukan. Lama perendaman adalah 4 jam. Setelah perendaman selesai, tulang segera diangkat, dan cairan perendaman dipindahkan ke wadah penguapan larutan gelatin yang telah berisi larutan gelatin dari tahap I dan II.

\section{d. Penguapan Gelatin Tulang Ikan Bandeng}

Larutan hasil eksraksi gelatin kemudian diuapkan menggunakan rotary evaporator vacum pada suhu $70{ }^{\circ} \mathrm{C}$.

\section{e. Pengeringan Gelatin Tulang Ikan Bandeng}

Gelatin pekat diletakkan dalam wadah stainless steel yang telah dialasi plastik dan diratakan. Kemudian dikering anginkan dengan sinar matahari selama 8 jam.

\section{f. Penentuan Waktu Perendaman Optimum Tulang Ikan bandeng}

Sebanyak 250 gr tulang kering direndam dalam larutan asam sitrat dengan konsentrasi optimum pada perlakuan $a$. Dengan perbandingan berat sampel dan volume pelarut adalah 1:3 dengan lama perendaman 12 jam. Selama perendaman dilakukan pengadukan. Setelah itu tulang dicuci dan disemprot dengan air. Perlakuan tersebut diulang secara triplo. Perlakuan diatas diulang dengan prosedur yang sama pada waktu perendaman 24 jam, 36 jam, 48 jam dan 60 jam. 


\subsubsection{Karakterisasi Gelatin Tulang Ikan bandeng}

a. Uji Organoleptik Gelatin Tulang Ikan bandeng (Soekarto, 1989)

Panelis diminta tanggapan pribadinya tentang kesukaan atau ketidak sukaan yang disertai tingkat kesukaannya. Uji organoleptik pada tulang ikan bandeng meliputi parameter bau, rasa dan warna. Rentang skala uji mutu hedonik untuk bau yaitu: sangat tidak anyir (4), tidak anyir (3), agak tidak anyir (2), anyir (1), sangat anyir (0). Sedangkan untuk rasa dengan 5 skala yaitu: sangat enak (4), enak (3), agak tidak enak (2), tidak enak (1) dan sangat tidak enak (0). Rentang skala untuk warna adalah: putih tulang (4), putih kekuningan (3), kuning keputihan (2), coklat kekuningan (1) dan coklat tua (0).

\section{b. Penentuan Kadar Air Secara Thermogravimetri (AOAC 1984)}

Sebanyak 0,5 gr sampel gelatin dimasukkan dalam cawan porselin, kemudian dimasukkan dalam oven dan dikeringkan pada suhu $105{ }^{\circ} \mathrm{C}$ selama 24 jam. Lalu didinginkan dalam desikator dan ditimbang hingga diperoleh berat konstan.

\section{c. Penentuan Kadar Abu (AOAC 1984)}

Cawan yang berisi sampel kering dimasukkan dalam tanur pada suhu $600{ }^{\circ} \mathrm{C}$ selama 6 jam, kemudian didinginkan dalam desikator dan ditimbang hingga didapat berat kostan.

\section{d. Penentuan Kadar Protein Total (Sudarmadji, et al, 1997)}

Sebanyak $10 \mathrm{mg}$ sampel dimasukkan ke dalam labu ukur dan diencerkan dengan aquades hingga tanda batas. Kemudian diambil $10 \mathrm{ml}$ dan dimasukkan dalam labu kjeldahl $500 \mathrm{ml}$ dan ditambah $10 \mathrm{ml} \mathrm{H}-\mathrm{HgO}(20: 1)$ sebagai katalisator. Kemudian didestruksi dengan cara dididihkan sampai menjadi jernih. Setelah dingin, dinding dalam labu kjeldahl dicuci menggunakan aquades kemudian dididihkan lagi selama 30 menit. Setelah dingin ditambahkan $140 \mathrm{ml}$ aquades dan $35 \mathrm{ml}$ larutan $\mathrm{NaOH}-\mathrm{Na}$ serta beberapa butiran zink. Selanjutnya didestilasi, destilat ditampung dalam erlen meyer yang berisi 25 ml larutan jenuh asam borat dan beberapa tetes indikator metil merah. Selanjutnya dititrasi menggunakan larutan $\mathrm{HCl} 0,02 \mathrm{~N}$ hingga terbentuk warna merah bata. Kadar protein dihitung menggunakan rumus.

\section{e. Uji Titik Leleh Gelatin Tulang Ikan Bandeng}

Sampel gelatin dimasukkan dalam beaker glass, selanjutnya ujung besi pada melting point apparatus dikenakan tepat menyentuh sampel. Kemudian melting point apparatus dihidupkan hingga sampel mulai meleleh dan tombol temperatur ditekan. Suhu yang tertera dalam termometer merupakan titik leleh dari sampel.

\section{f. Uji Kekuatan Gel pada Gelatin Tulang Ikan bandeng (Janah, 2007)}

Beban pada alat penetrometer ditimbang, kemudian sampel gelatin yang telah berbentuk gel (dalam larutan gelatin 5 $\%$ ) diletakkan tepat dibawah jarum penusuk penetrometer. Kemudian ditentukan waktu pengujian penetrasi yaitu waktu yang dibutuhkan untuk penekanan terhadap gelatin. Selanjutnya dilepaskan beban lalu dibaca skala penunjuk setelah alat berhenti.

\subsubsection{Analisa Data}

Pengolahan data hasil analisis dilakukan dengan metode deskriptif. Data yang diperoleh dari uji organoleptik dianalisis menggunakan metode Kruskal-Wallis. Penentuan perlakuan terbaik menggunakan metode De Garmo.

\section{HASIL DAN PEMBAHASAN}

\subsection{Pembuatan Gelatin Tulang Ikan Bandeng}

Tulang yang awalnya keras, menjadi lunak dan mengembang setelah direndam dalam larutan asam sitrat. Melunak dan mengembangnya tulang ini disebabkan terbebasnya protein yang semula tejebak 
didalam matriks kalsium dalam tulang. Maserasi dengan pelarut asam sitrat merupakan proses demineralisasi yang bertujuan untuk menghilangkan garam kalsium dan garam-garam lainnya sehingga diperoleh ossein. Tulang hasil perendaman kemudian dihidrolisis bertingkat. Proses ini disebut juga sebagai proses denaturasi untuk mengubah serat kolagen yang tidak larut dalam air menjadi larut dan mudah dicerna, yang disebut sebagai gelatin. Ikatan yang kemungkinan terpecah dalam proses ini adalah ikatan hidrogen, interaksi hidrofobik, ikatan ionik dan ikatan Van der waals yang terbentuk diantara rantai polipeptida sehingga terbukanya lipatan molekul (Winarno, 2002). Terpecahnya ikatan inilah yang menyebabkan berubahnya sifat kelarutan kolagen terhadap air. Larutan gelatin yang dihasilkan dari ekstraksi pada suhu $50{ }^{\circ} \mathrm{C}$ merupakan hasil terbaik, karena mengandung gelatin dalam konsentrasi $55 \%$. Ekstraksi pada suhu $65{ }^{\circ} \mathrm{C}$ bertujuan untuk mengubah serat kolagen yang masih belum terpecah pada suhu $50{ }^{\circ} \mathrm{C}$, demikian juga dengan hidrolisis pada suhu 80 ${ }^{\circ} \mathrm{C}$, sehingga kolagen dalam tulang ikan bandeng dapat dikonversi secara optimal menjadi gelatin. Ekstrak gelatin dipekatkan menggunakan rotary evaporator vacuum, yang bertujuan untuk memperoleh total solid gelatin. Ekstrak yang diperoleh dari pemekatan berupa ekstrak pekat yang berbau anyir (tajam). Rendemen gelatin yang dihasilkan dalam proses ini bervariasi sesuai dengan konsentrasi asam sitrat yang digunakan serta lama perendamannya.

Tabel 3. Rendemen gelatin tulang ikan bandeng berdasarkan variasi konsentrasi pelarut asam sitrat dengan lama perendaman 24 jam

\begin{tabular}{cc}
\hline $\begin{array}{c}\text { Gelatin asam } \\
\text { sitrat }(\boldsymbol{\%})\end{array}$ & Rendemen (\%) \\
\hline 1 & 1,85 \\
3 & 3,16 \\
5 & 5,14 \\
7 & 7,63 \\
9 & 8,39 \\
\hline
\end{tabular}

Tabel 4. Rendemen gelatin tulang ikan bandeng dengan konsentrasi asam sitrat $9 \%$

\begin{tabular}{cc}
\hline $\begin{array}{c}\text { Gelatin asam sitrat } \\
\text { (jam) }\end{array}$ & Rendemen $(\%)$ \\
\hline 12 & 6,51 \\
24 & 8,39 \\
36 & 9,19 \\
48 & 9,74 \\
60 & 8,07 \\
\hline
\end{tabular}

Terbebasnya kolagen dalam tulang ini mempermudah dalam proses konversi kolagen menjadi gelatin. Lama perendaman juga memberikan pengaruh yang positif terhadap jumlah gelatin yang dihasilkan. Hal ini dikarenakan waktu kontak antara molekul asam sitrat dan tulang semakin panjang, sehingga memiliki kesempatan lebih besar untuk saling berinteraksi. Namun pada saat perendaman mencapai 60 jam, kadar gelatin yang dihasilkan mulai menurun. Dengan semakin lamanya perendaman maka kolagen yang telah terputus ikatan hidrogennya akan terlarut dalam larutan asam (Jannah. Gelatin tulang Ikan bandeng dapat membentuk gel dengan konsentrasi $5 \%$. Gelasi terjadi dibawah suhu denaturasi atau titik perubahan gulungan helix (Hayashi \& Shin-chol Oh, 1982).

\subsection{Konsentrasi Optimum Asam Sitrat Dalam Pembuatan Gelatin Tulang Ikan bandeng (Chanos-chanos Forskal)}

Adapun parameter objektif dan subjektif pada produk gelatin tulang Ikan bandeng berdasarkan analisis yang digunakan dapat dilihat pada tabel 5. Penggunaan konsentrasi asam sitrat dalam penentuan konsentrasi optimum ini, dihentikan pada konsentrasi $9 \%$ yang mana kekuatan gelnya lebih tinggi dari gelatin pasaran. Karena kekuatan gel merupakan sifat utama untuk menentukan kualitas gelatin selain dari rendemen dan kadar protein. Pemilihan perlakuan terbaik yang dilakukan pada penelitian ini ditentukan dengan menggunakan metode De Garmo. Berdasarkan parameter objektif dan subjektif diperoleh gelatin terbaik pada perlakuan dengan perendaman menggunakan konsentrasi asam sitrat $9 \%$ selama 24 jam. 
Tabel 5. Hasil Analisis terhadap Parameter Objektif dan Subjektif pada Produk Gelatin Tulang Ikan bandeng

\begin{tabular}{llllll}
\hline \multicolumn{1}{c}{ Parameter } & \multicolumn{5}{c}{ Gelatin Asam Sitrat (\%) } \\
\cline { 2 - 6 } & $\mathbf{1}$ & $\mathbf{3}$ & $\mathbf{5}$ & $\mathbf{7}$ & $\mathbf{9}$ \\
\hline Parameter objektif & & & & & \\
Kadar air (\%) & 8,03 & 6,77 & 6,28 & 7,18 & 6,80 \\
Kadar abu & 0,40 & 0,23 & 0,155 & 0,135 & 0,132 \\
Kadar protein (\%) & 2,75 & 5,09 & 6,79 & 8,35 & 8,92 \\
Kekuatan gel (mm/g.dt) & 71,94 & 63,97 & 56,17 & 51,29 & 46,68 \\
Parameter subjektif & & & & & \\
Titik leleh (oc) & 90,83 & 85 & 82,5 & 80,83 & 76,17 \\
Warna & 1,16 & 2,28 & 3,31 & 3,15 & 3,40 \\
Aroma & 1,11 & 1,80 & 2,05 & 2,23 & 2,96 \\
Rasa & $\mathbf{1 , 1 6}$ & $\mathbf{1 , 6 7}$ & $\mathbf{1 , 8 5}$ & $\mathbf{2 , 2 9}$ & $\mathbf{2 , 6 1}$ \\
\hline
\end{tabular}

\subsection{Kadar Protein}

Gelatin tulang Ikan bandeng yang diperoleh dengan perendaman menggunakan asam sitrat $5 \%$ selama 6 hari memiliki kadar protein sebesar 4,69 \% (Jannah, 2007: 55). Nilai ini menunjukkan gelatin yang dipasaran maupun gelatin asam sitrat masih di bawah standar SIGMA yakni 87,26 \%. Kadar protein dalam gelatin meningkat sesuai dengan adanya penambahan konsentrasi asam sitrat. Hal ini dimungkinkan karena dengan meningkatnya konsentrasi asam sitrat, yang berarti jumlah molekul asam sitrat dalam larutan tersebut bertambah sehingga kerapatan molekulnya semakin besar. Kemungkinan untuk molekul asam sitrat bertabrakan dengan molekul kalsium fosfat dalam tulang semakin besar. Sehingga mengakibatkan asam sitrat bekerja lebih efektif dalam pengikatan mineral kalsium. Dengan demikian jumlah kolagen yang terbebas dan dapat dikonversi menjadi gelatin semakin banyak. Kemungkinan tersebutlah yang membuat kadar protein meningkat seiring dengan penambahan konsentrasi asam sitrat.

\subsection{Kadar Abu}

Kadar abu gelatin tulang bandeng yang diperoleh pada penelitian berkisar antara $0,40 \%-0,132 \%$. Gelatin dengan kadar abu tertinggi adalah asam sitrat $1 \%$ yakni $0,40 \%$ sedangkan pada gelatin asam sitrat $9 \%$ kadar abunya adalah $0,132 \%$. Jumlah ini sedikit berbeda dengan kadar abu dalam gelatin yang beredar dipasaran $\left(\begin{array}{ll}0 & \%\end{array}\right)$. Kadar abu dalamgelatin tulang Ikan bandeng hasil penelitian ini telah memenuhi standart dari SNI (maksimal 3,25 \%) maupun SIGMA $(0,52 \%)$. Selama perendeman tulang dalam asam sitrat terjadi demineralisasi dimana kalsium tulang dalam bentuk kalsium fosfat diikat oleh asam sitrat menjadi kalsium sitrat.

\subsection{Kekuatan Gel}

Gelatin dengan kekuatan gel terbaik adalah pada perlakuan dengan asam sitrat 9\%(46,68 mm/g.dt) sedangkan pada gelatin yang dihasilkan dari perlakuan menggunakan asam sitrat $1 \%$ adalah $71,77 \mathrm{~mm} / \mathrm{g}$.dt. Gelatin yang beredar di pasaran memiliki kekuatan gel $55,76 \mathrm{~mm} / \mathrm{g}$.dt, nilai ini menunjukkan bahwa gelatin asam sitrat $9 \%$ memiliki kekuatan gel yang lebih stabil. Pengukuran kekuatan gel ini dilakukan menggunakan alat yang disebut penetrometer, dengan cara pengujian penetrasi yaitu waktu yang dibutuhkan untuk penekanan terhadap sampel yang mengandung gelatin $5 \%$. Kekuatan gel dengan nilai terendah adalah yang memiliki kualitas gel terbaik, karena pada metode ini lamanya waktu penusukan menjadi acuan dalam penentuan nilai kekutan gel sampel. Semakin lama waktu penusukan maka angka yang diperoleh semakin kecil, begitu juga sebaliknya. Setiap penambahan asam sitrat 
akan menyebabkan kenaikan kekuatan gel pada gelatin. Sifat ini terkait dengan meningkatnya kadar protein disetiap penambahan asam sitrat. Dimungkinkan dengan bertambahnya kadar protein maka keberadaan asam amino jenis prolin dan hidroksiprolin juga semakin meningkat. Gelatin merupakan polipeptida yang terdiri atas ikatan kovalen dan ikatan peptida antara asam-asam amino yang membentuknya. Polipeptida ini memiliki dua atom terminal, ujung kiri mengandung gugus amino dan ujung kanan mengandung gugus karboksil. Kedua ujung itu memungkinkan untuk gelatin membentuk ikatan hidrogen dengan molekul gelatin lainnya, ataupun dengan molekul air. Asam amino 4-hidroksiprolin memiliki dua gugus fungsi yang memungkinkan untuk membentuk ikatan hidrogen, yakni atom $\mathrm{H}$ dari gugus $\mathrm{OH}$, atom $\mathrm{H}$ dan atom $\mathrm{O}$ dari gugus karboksil. Hidroksiprolin dan prolin dikatakan sebagai penstabil gel daripada gelatin.

\subsection{Titik Leleh}

Hasil analisis titik leleh gelatin tulang Ikan bandeng menunjukkan penurunan seiring dengan meningkatnya penambahan konsentrasi asam sitrat. Pada saat perendaman dengan asam sitrat $1 \%$, kolagen yang terbebas dari mineral belum mengalami interaksi dengan asam sitrat. Sehingga diasumsikan serat kolagen yang terbebas masih dalam kondisi utuh, dengan kemungkinan kecil mengalami pemutusan ikatan. Karena konsentrasi asam yang digunakan sangat rendah. Pada perendaman dengan asam sitrat $3 \%$, kolagen yang terbebas diasumsikan mulai mengalami interaksi dengan asam sitrat, begitu juga pada perendaman dengan asam sitrat $5 \%, 7 \%$ \& 9 $\%$. Semakin tinggi konsentrasi asam sitrat, kemungkinan untuk terjadinya interaksi antara asam sitrat dengan kolagen semakin besar. Pada konsentrasi asam sitrat yang tinggi, kolagen mengalami denaturasi, dimana rantai kolagen yang diperoleh lebih pendek daripada kolagen yang diperoleh dari konsentrasi asam sitrat yang rendah. Dengan semakin panjang rantai polipeptida, titik lelehnya semakin tinggi. Kemungkinan inilah yang menyebabkan adanya penurunan titik leleh pada setiap penambahan konsentrasi asam sitrat.

\subsection{Kadar Air}

Kadar air dalam gelatin tulang bandeng ini telah memenuhi standar dari SNI (maksimal 16\%) maupun SIGMA (11,45\%). Kandungan air dalam gelatin tulang Ikan bandeng $9 \%$ adalah hampir sama dengan kadar air pada gelatin yang beredar dipasaran. Hal ini menunjukkan proses evaporasi dan pengeringan pada gelatin tulang Ikan bandeng sudah tepat. Ketahanan dari gelatin pasaran dengan gelatin tulang Ikan bandeng terhadap serangan mikroba kemungkinan adalah sama.

\subsection{Aroma}

Tingkat kesukaan panelis terhadap rasa produk berkisar antara 1,15-2,62 dimana tingkat kesukaan panelis terhadap rasa tertinggi terdapat pada perlakuan asam sitrat 9 $\%$ dan terendah pada perlakuan asam sitrat 1 $\%$. Terdapat perbedaan yang sangat nyata diantara gelatin tulang Ikan dengan gelatin tulang sapi (gelatin pasaran). Hal ini dapat disebabkan oleh aroma gelatin tulang Ikan Bnadeng yang relatif agak tidak anyir, sedangkan gelatin pasaran memiliki rasa yang sangat tidak anyir. Berdasarkan analisis Kruskal-Wallis terhadap rasa diperoleh nilai $\mathrm{P}$ value $(0,000)<$ a 0,05 (Lampiran 8 ). Hal ini berarti bahwa penambahan konsentrasi asam sitrat tidak berpengaruh sangat nyata terhadap rasa gelatin tulang Ikan bandeng.

\subsection{Lama Perendaman Optimum Dalam Pembuatan Gelatin Tulang Ikan Bandeng (Chanos-chanos Forskal)}

Dalam tahap ini variasi waktu perendaman yang digunakan adalah 12 jam, 24 jam, 36 jam, 48 jam dan 60 jam. Gelatin yang dihasilkan diuji kualitasnya dengan menganalisa beberap sifat fisik maupun organoleptiknya. Pemilihan perlakuan terbaik yang dilakukan pada penelitian ini ditentukan dengan menggunakan metode De Garmo. Diperoleh gelatin dengan kualitas terbaik pada pada perlakuan perendaman dengan asam sitrat $9 \%$ selama 48 jam.

\subsection{Kadar Protein}

Berdasarkan data yang diperoleh, kadar protein gelatin meningkat seiring penambahan waktu perendaman, namun pada perendaman 
60 jam kadar protein menurun. Hal ini dikarenakan dengan semakin lamanya waktu perendaman maka kolagen yang terbentuk akan terlarut dalam larutan asam (Jannah, 2007), akibatnya kolagen yang dapat dikonversikan menjadi gelatin berkurang. Semakin lama waktu perendaman, maka kesempatan dari asam sitrat untuk membebaskan kolagen dari matrik kalsium semakin besar. Terbentuknya kologen yang bebas ini akan memudahkan dalam proses konversi kolagen menjadi gelatin melalui ekstraksi bertingkat.

\subsection{Kadar Abu}

Kadar abu mengalami penurunan dengan semakin lamanya waktu perendaman. Selama perendeman tulang dalam asam sitrat mengalami demineralisasi dimana kalsium tulang dalam bentuk kalsium fosfat diikat oleh asam sitrat menjadi kalsium sitrat. Dengan bertambahnya waktu perendaman, maka kesempatan untuk saling berinteraksi semakin panjang, sehingga semakin banyak kalsium yang dapat diikat oleh molekul asam sitrat.

\subsection{Kekuatan gel}

Setiap penambahan waktu perendaman menyebabkan kenaikan kekuatan gel, namun pada perendaman 60 jam kekuatan gel menurun, hal ini terkait dengan penurunan kadar protein pada gelatin hasil perendaman selama 60 jam. Gelatin tulang bandeng mulai membentuk gel pada suhu $15 \mathrm{C}$ dan mencair kembali pada suhu ruang (bertahan dalam bentuk gel selama 15 menit).

\subsection{Titik Leleh}

Setiap penambahan waktu perendaman maka titik leleh gelatin akan menurun. Penurunan titik leleh dipengaruhi oleh semakin lamanya perendaman. Semakin lama perendaman berarti waktu kontak antara asam sitrat dan kolagen yang terbebas semakin besar, sehingga kemungkinan untuk kolagen mengalami denaturasi semakin besar pula. Semakin lama perendaman berarti kolagen yang diperoleh semakin pendek.

\subsection{Identifikasi Gugus Fungsi Gelatin Dengan Spektrofotometer FT-IR}

Spektra inframerah gelatin tulang Ikan bandeng dengan perlakuan asam sitrat $9 \%$ dan lama perendaman 48 jam menunjukkan adanya pita serapan kuat pada bilangan gelombang 3459,09 $\mathrm{cm}$ yang merupakan regangan dari $\mathrm{OH}$ intermolekuler. Serapan ini mengalami overlap dengan serapan lemah yang dihasilkan oleh regangan simetri dari $\mathrm{N}-$ $\mathrm{H}$ amida primer pada $3219,94 \mathrm{~cm}$ dari amina. Serapan lemah pada bilangan gelombang $1642,27 \mathrm{~cm}$ sebagai akibat dari vibrasi tekuk $\mathrm{N}-\mathrm{H}$ amina primer. Serapan kuat pada bilangan gelombang 1742,57 yang merupakan regangan $\mathrm{C}=\mathrm{O}$ dari amida sekunder.

Tabel 6. Hasil analisis terhadap parameter objektif dan subjektif pada produk gelatin tulang Ikan bandeng (berdasarkan Variasi Lama Perendaman dengan menggunakan asam sitrat $9 \%$ )

\begin{tabular}{llllll}
\hline \multirow{2}{*}{\multicolumn{1}{c}{ Parameter }} & \multicolumn{5}{c}{ Lama Perendaman (jam) } \\
\cline { 2 - 6 } & $\mathbf{1 2}$ & $\mathbf{2 4}$ & $\mathbf{3 6}$ & $\mathbf{4 8}$ & $\mathbf{6 0}$ \\
\hline Parameter Obyektif & & & & & \\
Kadar air (\%) & 9,11 & 6,80 & 7,63 & 6,68 & 6,09 \\
Kadar abu (\%) & 0,199 & 0,132 & 0,098 & 0,033 & 0 \\
Kadar protein (\%) & 7,69 & 8,92 & 9,08 & 9,56 & 8,58 \\
Kekuatan gel (mm/g.dt) & 55,83 & 46,68 & 41,74 & 38,72 & 40,08 \\
Titik leleh $\left({ }^{\circ} \mathrm{C}\right)$ & 88,83 & 76,17 & 74,67 & 71 & 71,83 \\
Parameter Subyektif & & & & & \\
Warna & 3,04 & 3,40 & 3,28 & 3,80 & 3,51 \\
Aroma & 2,36 & 2,96 & 2,99 & 3,00 & 3,03 \\
Rasa & $\mathbf{2 , 5 7}$ & $\mathbf{2 , 6 1}$ & $\mathbf{2 , 8 0}$ & $\mathbf{2 , 8 5}$ & $\mathbf{2 , 9 1}$ \\
\hline
\end{tabular}


Pada bilangan gelombang 1617,2 terjadi serapan lemah oleh $\mathrm{C}=\mathrm{C}$ aromatik yang dimungkinkan berasal dari asam amino dengan rantai samping aromatik yang terkandung dalam gelatin. Hal ini didukung oleh adanya serapan lemah pada bilangan gelombang 1461,94 sebagai akibat dari vibrasi regangan $=\mathrm{C}-\mathrm{H}$ aromatik. Pita serapan kuat pada bilangan gelombang $1541,02 \mathrm{~cm}$ adalah vibrasi tekuk $\mathrm{N}-\mathrm{H}$ dari amida sekunder yang diikuti oleh serapan dari regangan $\mathrm{C}-\mathrm{N}$ amida sekunder pada bilangan gelombang $1306,68 \mathrm{~cm}$. Serapan kuat pada bilangan gelombang 605,61 merupakan akibat dari vibrasi tekuk NCO dari amida sekunder. Regangan $\mathrm{C}-\mathrm{O}$ dari alkohol sekunder memberikan serapan kuat pada bilangan gelombang 1080,06 $\mathrm{cm}$ sebagai akibat dari tekukan $\mathrm{O}-\mathrm{H}$ keluar bidang. Dari hasil analisis spektra FT-IR di atas diketahui gugus fungsi yang terdapat pada sampel adalah gugus $-\mathrm{OH}, \mathrm{C}-\mathrm{O}, \mathrm{N}-\mathrm{H}$ dari amida sekunder yang didukung dengan adanya gugus $\mathrm{C}-\mathrm{N}$, $\mathrm{C}=\mathrm{O}$ dan juga $\mathrm{NCO}$ dari amida sekunder, sebagai gugus-gugus fungsi utama pada gelatin.

\section{PENUTUP}

Berdasarkan hasil penelitian yang didapat, maka dapat disimpulkan bahwa:

1. Konsentrasi optimum asam sitrat asam sitrat yang digunakan dalam pembuatan gelatin tulang Ikan bandeng adalah $9 \%$.

2. Lama perendaman optimum dalam pembuatan gelatin tulang Ikan bandeng dengan konsentrasi asam sitrat $9 \%$ adalah 48 jam.

3. Karakteristik gelatin tulang Ikan bandeng dengan perlakuan asam sitrat 9 $\%$ dan lama perendaman 48 jam (sebagai perlakuan optimum) adalah memiliki kadar air 6,68\%, kadar abu $0,033 \%$ kadar protein $9,56 \%$,kekuatan gel $38,72 \mathrm{~mm} /$ gr.dt, titik leleh $71{ }^{\circ} \mathrm{C}$, warna 3,8 (putih), aroma 3,00 (tidak anyir), rasa 2,85 (enak). Gugus fungsi yang dapat diidentifikasi dari spektra FT-IR gelatin tulang ikan bandeng. diantaranya adalah $\mathrm{C}-\mathrm{N}, \mathrm{N}-\mathrm{H}, \mathrm{C}=\mathrm{O}$, $\& \mathrm{O}-\mathrm{H}$.

\section{DAFTAR PUSTAKA}
Anonymous., $\quad 2003, \quad$ Gelatin, http://www.ristek.go.id, Diakses tanggal 27 juli 2007. Eastoe J.E., 1956, The Amino Acid Compotition Of Fish Collagen And Gelatin, Dalmeny Avenue, London.

Eastoe J.E., 1956, The Amino Acid Compotition Of Fish Collagen And Gelatin, Dalmeny Avenue, London.

Wahyuni M., \& Rosmawati., 2003, Perbaikan Daya Saing Industri Pengolahan Perikanan Melalui Pemanfaatan Limbah Non Ekonomis Ikan Menjadi Gelatin, Departemen Kelautan dan Perikanan Republik Indonesia. http://www.dkp.go.id/content, diakses tanggal 27 Juli 2007 